NBER WORKING PAPER SERIES

\title{
THE PRICE IMPACT OF JOINING A CURRENCY UNION: EVIDENCE FROM LATVIA
}

\author{
Alberto Cavallo \\ Brent Neiman \\ Roberto Rigobon \\ Working Paper 20225 \\ http://www.nber.org/papers/w20225
NATIONAL BUREAU OF ECONOMIC RESEARCH
1050 Massachusetts Avenue
Cambridge, MA 02138
June 2014

We thank Dennis Carlton and Raphael Schoenle for very helpful comments and suggestions. Diego Aparicio provided outstanding research assistance. The views expressed herein are those of the authors and do not necessarily reflect the views of the National Bureau of Economic Research.

At least one co-author has disclosed a financial relationship of potential relevance for this research. Further information is available online at http://www.nber.org/papers/w20225.ack

NBER working papers are circulated for discussion and comment purposes. They have not been peerreviewed or been subject to the review by the NBER Board of Directors that accompanies official NBER publications.

(C) 2014 by Alberto Cavallo, Brent Neiman, and Roberto Rigobon. All rights reserved. Short sections of text, not to exceed two paragraphs, may be quoted without explicit permission provided that full credit, including $\odot$ notice, is given to the source. 
The Price Impact of Joining a Currency Union: Evidence from Latvia

Alberto Cavallo, Brent Neiman, and Roberto Rigobon

NBER Working Paper No. 20225

June 2014, Revised August 2014

JEL No. E3,F3,F4

\begin{abstract}
Does membership in a currency union matter for a country's international relative prices? The answer to this question is critical for thinking about the implications of joining (or exiting) a common currency area. This paper is the first to use high-frequency good-level data to provide evidence that the answer is yes, at least for an important subset of consumption goods. We consider the case of Latvia, which recently dropped its pegged exchange rate and joined the euro zone. We analyze the prices of thousands of differentiated goods sold by Zara, the world's largest clothing retailer. Price dispersion between Latvia and euro zone countries collapsed swiftly following entry to the euro. The percentage of goods with nearly identical prices in Latvia and Germany increased from 6 percent to 89 percent. The median size of price differentials declined from 7 percent to zero. If a large number of firms also behave this way, these results suggest that membership in a currency union has significant implications for a country's real exchange rate.
\end{abstract}

Alberto Cavallo

MIT Sloan School of Management

100 Main Street, E62-512

Cambridge, MA 02142

and NBER

acavallo@mit.edu

Brent Neiman

University of Chicago

Booth School of Business

5807 South Woodlawn Avenue

Chicago, IL 60637

and NBER

brent.neiman@chicagobooth.edu
Roberto Rigobon

MIT Sloan School of Management

100 Main Street, E62-516

Cambridge, MA 02142

and NBER

rigobon@mit.edu 


\section{Introduction}

Does membership in a currency union matter for a country's real exchange rate? The answer to this question is critical for thinking about the implications of joining or exiting a common currency area. For example, popular discussion of the possibility that countries like Greece or Portugal might exit the euro zone often presumes that the country's prices relative to other countries, when translated into a common currency, will change. And in fact, one of the central arguments made by policymakers in support of the common currency union was that it would lead to price convergence.

By contrast, standard models in open-economy macroeconomics predict that changing the currency unit per se should have little or no impact on relative prices once prices have had a chance to adjust. ${ }^{1}$ This is particularly the case when the change is not associated with other policies governing tariffs or taxes, and when the change in regime is between a hard peg and a currency union, since neither has any nominal volatility.

In the face of such a disparity between theory and common belief, well identified empirical evidence is particularly important. Experiments offering such identification are rarely available in macroeconomics, but the entry of Latvia to the euro zone on January 1st, 2014 is a helpful exception. This paper is the first to use high-frequency good-level data to demonstrate that, at least for several thousand goods sold by one of the world's largest apparel retailers, joining a currency union does have economically meaningful implications for a country's prices and real exchange rate.

This natural experiment is particularly helpful because Latvia's entry to the euro zone did not carry with it meaningful additional changes in policies governing the cross-border flows of goods or people. Latvia has been a member of the European Union (EU) since 2004. Most relevant laws, such as those governing tariffs or antitrust rules, are set at the EU level. ${ }^{2}$ The change was fully anticipated and well communicated in advance. Finally, Latvia is so small relative to the existing set of euro zone countires that it's entry surely did not have important general equilibrium effects on activity in the rest of the euro zone countries.

\footnotetext{
${ }^{1} \mathrm{~A}$ large theoretical and empirical literature characterizes the decision of importers and exporters to price using local currency pricing (LCU) or producer currency pricing (PCP). The primary repercussion of the currency unit decision, however, is to set passthrough to either zero (as with LCP) or one (as with PCP) during the interval when prices are sticky. The impact of the choice of currency unit only persists after price adjustment due to complementarities with other sticky prices, and this impact is typically muted. See, for instance, Friberg (1998), Bacchetta and Wincoop (2005), Devereux, Engel, and Storgaard (2004), Goldberg and Tille (2008), and Gopinath, Itskhoki, and Rigobon (2010).

${ }^{2}$ As elaborated in Cavallo, Neiman, and Rigobon (2014), there is no law requiring companies to set the same retail price across the euro zone countries.
} 
We scrape daily prices off the internet web page of Zara, the world's largest clothing retailer, for a monthly average of roughly five thousand differentiated goods sold in dozens of countries and find that price dispersion between Latvia and euro zone countries collapsed swiftly following entry to the euro. All prices, previously denominated in lats, the Latvian currency, were changed to euros on January 1st, 2014. The percentage of goods with identical euro prices in Latvia and Germany very rapidly increased from 6 percent to 89 percent and the median size of price differentials declined from 7 percent to zero. We do not find meaningful differences in other characteristics such as the rate of new product introductions. ${ }^{3}$

These results complement our previous work that considered the importance of currency regimes for price setting in a larger cross section of countries, retailers, and sectors. Cavallo, Neiman, and Rigobon (2014) compared countries inside and outside of the euro zone to demonstrate that tradable good prices are far more likely to be equal within a common currency area than outside of it, even compared to pegged exchange rate regimes. That analysis, however, left open the question of whether and how quickly such a pattern might emerge in response to a change over time in a country's exchange rate policy. We now document the time-series of this pattern during the change in Latvia's currency regime from a pegged exchange rate to a member of the euro zone.

There is a significant amount of work studying price convergence, or the lack thereof, associated with the entry of countries into the euro zone in 1999. Goldberg and Verboven (2005) demonstrate that euro zone auto prices converged following the introduction of the common currency, while others including Parsley and Wei (2008) and Engel and Rogers (2004) do not find evidence for such a change. ${ }^{4}$ Other work, such as Rose (2000) and Blanchard and Giavazzi (2002), have examined the impact of the euro on other economic objects such as gross trade flows and current account imbalances. Our study differs in concept from these earlier papers both due to the nature of the data and the nature of the shock.

We consider the planned entry of a small and pegged country to a much larger and well established currency union, a situation quite different from what occurred in 1999 . We are only aware of one other paper that examines the pricing impact of entry into a currency union using highly disaggregated or micro data. Dvir and Strasser (2014) study relative prices in Europe of about 150 precisely matched car models. Their data is annual and includes Slovenia, Cyprus, Malta, Slovakia, and Estonia, all of which adopted the euro in the middle of their span of data.

\footnotetext{
${ }^{3}$ The short span of post-euro data, however, implies that we lack much power to assess this and other pricing moments. For example, we cannot yet conclude whether there have been changes in the size or frequency of price changes other than those immediately associated with Latvia's adoption of the euro.

${ }^{4}$ See also Gil-Pareja and Sosvilla-Rivero (2008, 2012).
} 
They estimate a drop of about 1 percent in the average product-level real exchange rates associated with entry to the euro zone.

Finally, we are related to a growing literature using online and scraped internet prices to measure cross-border relative prices for identical goods. This literature includes Simonovska (2011), Boivin, Clarck, and Vincent (2012), and Gorodnichenko and Talavera (2014).

We proceed as follows. First, in Section 2, we briefly describe the history of Latvia's exchange rate and its process of entry into the euro zone. In Section 3 we discuss Zara's operation in Latvia and elsewhere in the euro zone, including how its online prices relate to its offline prices. Section 4 presents histograms and time series plots which demonstrate the dramatic change in the distribution of good-level real exchange rates before and after the euro zone, and highlight that this change occurred quite rapidly, starting in late 2013 and ending within weeks of Latvia's adoption of the euro. We then conclude.

\section{A Brief History of Latvia's Exchange Rate}

Latvia joined the EU in 2004 and at that time used its own currency called the lat. Lats were valued at nearly 2 euros in 2000 but steadily depreciated before a peg was implemented in early 2005. Between mid-2005 and late-2013, the lat's end-of-month value was always in the range of 1.40 to 1.47 euros and the standard deviation of the monthly log exchange rate was a very low 0.008. This peg should be thought of as particularly credible since this period with a tightly fixed currency included a horrific recession in 2008-2009 in which real GDP declined by roughly 20 percent. ${ }^{5}$

Inflation rates were moderate to high for much of the 2000s, peaking above 15 percent in 2008 . This among other features of the economy scuttled initial plans to join the euro zone in 2008. Inflation remained below 5 percent, however, from 2009 onward, setting the stage for the January 1, 2014 entry date to the euro.

On January 1st ("changeover day"), bank balances, pensions, salaries, loans, and financial instruments (stocks, bonds, etc.) were all converted into euros at the official rate of about 1.42 euros per lat. There was a two week grace period in which both currencies were accepted as legal tender, though all change had to be given in euros. After January 15th, only the euro remained as legal tender. ${ }^{6}$ Banks were required to exchange lats for euros at the official exchange rate without

\footnotetext{
${ }^{5}$ See Bems and di Giovanni (2014) for a discussion of Latvia's recession and a characterization of its external adjustment during this period.

${ }^{6}$ From October 1st, 2013 to June 30st, 2014 there was a compulsory "dual price display" period, in which traditional offline stores had to display prices in both currencies, with prices converted at the official rate. Online
} 
commission for the first six months after the new currency's introduction.

Nearly all relevant goods and factor market regulations are set at the level of the EU, not the euro zone. This implies that the change in Latvia's monetary regime is a well identified shock. Other important policies such as the level of tariffs, for example, did not change at the same time. Latvia was the only country to join the euro zone in January 2014. The previous country to join was Estonia in 2011 and Lithuania has plans to join in 2015.

\section{Zara: A Global Apparel Retailer}

Zara is the world's largest clothing retailer. Founded in 1974, it is owned by Inditex (a company with market capitalization over $\$ 85$ billion at the time of writing) and is based in Spain. Zara's global sales in 2013 exceeded $\$ 13$ Billion. It operates nearly 2,000 offline stores world-wide and operates 4 in Latvia, 126 in France, 99 in Italy, 72 in Germany, and 45 in the United States. ${ }^{7}$ Zara sells online in 24 countries, including 19 in Europe.

Zara does not yet sell online in Latvia, but it does have a Latvia-specific web page which posts prices for its goods. Its customer service department clarified Zara's policy that their "store and online shop share the same pricing," up to occasional in-store sales. ${ }^{8}$ Note that this implies that the law of one price typically holds even within-country for Zara. As we argue in Cavallo, Neiman, and Rigobon (2014), this is a far more common feature of pricing than is typically thought and is also the case for a large share (if not the majority) of non-grocery products sold in the United States by the 10 largest retailers. For this reason, prices on these products are well-suited to examining price differences associated with country borders. Further, by focusing on prices from the same retailer in multiple countries, we eliminate the retailer-specific component of price heterogeneity, shown in Handbury and Weinstein (2013) and Nakamura, Nakamura, and Nakamura (2011) to be a key driver of cross-regional variation in pricing behavior in the U.S. We acknowledge, however, that in other sectors there is convincing evidence of large within-country price dispersion, such as in Kaplan and Menzio (2013) for (predominantly) groceries or Dvir and Strasser (2014) for cars.

To corroborate that Zara's online prices equal their offline prices, we selected 10 random items and verified that prices were identical in the U.S. web page and in each of two Zara stores near

stores have the option to display prices in both currencies using a currency conversion calculator that is easily accessible for consumers. This requirement does not apply to advertising materials. See Regulation No. 178 (2013) for additional details.

${ }^{7}$ Clothing and footwear receive a 6 percent weight in Latvia's CPI.

${ }^{8}$ Purchases made on Zara's web page may not be shipped to countries other than that hosting the web page. At time of check out, the "Country" field in the shipping information cannot be changed. 
Boston. Further, to try to calibrate the importance of in-store sales, we asked sales clerks at the offline Zara stores about the percentage of items that were on sale. They responded "less than 10 percent." We then counted ourselves and found sales on a subset of 6 racks out of a total of 104 racks, implying far fewer than 5 percent of the items were on sale.

Starting in September 2012 and through May 2014, we collected these pricing data for Zara items in Latvia and other countries by "scraping" their web pages, matching identical goods across countries using the product identification code. We collected the prices each day and aggregated them to form a dataset of weekly prices. Aside from occasional problems with the scraping algorithm, our data in principle capture the prices of all goods sold online by Zara. We do not have information about the quantities sold of each item. For the relatively rare periods in which scraping problems resulted in censored data, we simply copy forward the last observed price for each item in each country. We refer the reader to Cavallo, Neiman, and Rigobon (2014) and Cavallo (2012) for additional details on the data collection procedure and country and time coverage.

By EU law, prices are quoted online in Europe inclusive of tax rates. Latvia's value added tax rate of 21 percent is similar to that in other euro zone countries like France (20 percent), Germany (19 percent), and Italy (21 percent). Major tax rates did not change at the time of Latvia's entry to the euro zone.

Table 1 lists key features of the data for Latvia, France, Italy, Germany, the United States, and for all 81 countries in our data with prices for Zara ("World"), both before and after Latvia's entry into the euro zone. The first column of Panel A shows that during 2012-2013, Zara sold an average of about 5,000 distinct items worldwide each month. The 25th, 50th, and 75th percentile prices, translated into euros, equal $€ 25.95$, $€ 39.95$, and $€ 60.81$.

The next five columns show the equivalent statistics, together with the currency regimes, for the five countries Latvia, France, Italy, Germany, and the United States. During 2012-2013, Latvia's lat was pegged at a value of about $€ 1.4$, while the United States dollar floated at an average value of $€ 0.75$. All individual countries had an average number of distinct products per month that ranged from 3,400 to 3,800, equal to about 70 percent of the total global number of products. This confirms the large overlap in the sets of Zara products available in each country. The price distributions of France, Italy, and Germany (the euro zone countries) appear highly similar, with the typical good priced at about $€ 40$. The median price in Latvia is slightly lower at about $€ 37$ and in the United States is higher at about $€ 44.5 .^{9}$

\footnotetext{
${ }^{9}$ The vast majority of Zara's prices are an integer number of euros or end with .95 or .99, a pattern that can be seen in Table 1. Could these price points explain our results? Imagine that before Latvia joined the euro, Zara wished to price in Latvia at a level ending with a "95" or "99" that came closest to their median price in the euro
} 
Panel B of Table 1 reports the equivalent information but for January to May 2014, after Latvia adopted the euro. The average number of products available increased in 2014 all around the world and increased similarly in each country, shifting the distribution from roughly 3,500 in each country to 4,000 in each country. ${ }^{10}$ In terms of these particular moments of the pricing distribution, nothing changes in the pre-existing euro zone countries. Latvia's median price, however, jumps by 8 percent to converge to that in the rest of the euro zone. The euro value of prices in the United States and world as a whole do change a bit comparing 2012-2013 and 2014, though this likely reflects nominal exchange rate movements with the euro.

In sum, we capture the prices on thousands of goods sold by one of the world's largest multinational retailers. Comparing basic characteristics of the data before and after Latvia's entry to the euro, one sees no meaningful change in these prices or the set of goods available when considering countries other than Latvia. This supports the identification assumption in this paper that the primary shock occurring on January 1st 2014 was Latvia's change in currency regime, not some other change impacting Zara's prices worldwide or in other euro zone countries.

\section{Price Convergence and the Euro}

In Cavallo, Neiman, and Rigobon (2014), we demonstrated that prices of the same good were dramatically more likely to be equalized across countries in a currency union compared with other exchange rate regimes including hard pegs. But, due to lack of data spanning a change in currency regime, this inference came purely from analysis of the cross-section of countries. Here, we consider time-series variation in the relative price of goods sold in Latvia versus other euro zone countries like France, Italy, and Germany (as well as the United States as a reference point). We focus on the difference in these relative prices in 2012-2013, before Latvia adopted the euro, compared to 2014, when Latvia became part of the euro zone.

Let $p_{i}(z, t)$ denote the $\log$ price in local currency of good $z$ in country $i$ in week $t$. We define $e_{i j}(t)$ to be the log of the value of one unit of country $j$ 's currency translated into country $i$ 's currency. The log good-level RER $q_{i j}(t)$ is defined as the difference between prices in countries $i$

zone of 39.95. They could have charged 27.95 lats - itself one of the most common price levels (in local currency) in the euro zone - and gotten well within 1 percent of the euro zone price. Were Zara instead to only price at levels ending as 5.95 or 9.99, for instance, the intervals would be larger and more able to explain, mechanically, our results. This would then simply raise the puzzle of why Zara would put so much emphasis on the psychology of the price level (or, perhaps for some readers, would put a quantative value on the importance of that psychology). See Friberg and Matha (2004) for evidence on the importance of these psychological pricing points at the time of the euro's creation.

${ }^{10}$ This minor increase is likely a reflection of the differences in seasons. Our 2014 data only include the winter and early spring, whereas the 2012-2013 period averages across all four seasons. 
and $j$ after being translated into a common currency:

$$
q_{i j}(z, t)=p_{i}(z, t)-e_{i j}(t)-p_{j}(z, t)
$$

It equals zero when prices in $i$ and $j$, after translating to a common currency, are equal.

\subsection{Relative Price Distribution Before and After Joining the Euro}

Figure 1 plots the distribution of $q_{i j}(z, t)$ for all goods in our dataset available in both $i$ and $j$, where $i=\{$ France, Germany, Italy, United States $\}$ and $j=$ Latvia. The y-axis values capture the percentage of observations corresponding to a given $\mathrm{x}$-axis bin. We include all available data for each bilateral pair, i.e. all products sold in both Latvia and in each of the respective countries, and we pool the prices across all available weeks from 2012 onward. The number of distinct products included in each of these histograms averages nearly 10,000. This corresponds to an average number of products in a given month of about 3,500, which is lower because products enter and exit over the course of the year. Each bilateral pair (i.e. Latvia together with each of the four countries) includes two histograms, labeled "Latvia Pegged" and "Latvia in Euro". These histograms separately plot data from the regime before and after Latvia's entry to the euro zone, 2012-2013 and 2014, respectively.

Starting with France, one notes a striking change in the distribution of relative prices with Latvia in the "Latvia Pegged" vs. "Latvia in Euro" regimes. Before joining the euro, Latvia's prices differed significantly from France's, commonly by magnitudes of 15 or 20 percent. Less than 10 percent of prices are within 1 percent of price equalization. We remind the reader that these differences did not emerge due to price rigidity and nominal exchange rate fluctuations because Latvia had a hard peg with the euro and therefore had zero nominal volatility with France during both of these regimes.

The picture looks quite different after Latvia joins the euro. Though there are still some goods with large price differences, the majority of prices were virtually identical in France and Latvia in 2014 as seen by the spike in mass corresponding to the 0 value on the $\mathrm{x}$-axis.

The pattern of relative prices for Latvia with Germany or Italy look essentially the same as

with France. In all cases, there was significant price dispersion prior to Latvia joining the euro which collapses after the currency regime change. The reason for the similarities across the plots of France, Germany, and Italy, of course, is the finding in Cavallo, Neiman, and Rigobon (2014) that prices are highly similar in those three countries themselves.

Finally, we include a histogram of relative prices with the United States to demonstrate that 
2014 wasn't associated with a global convergence of Zara's prices. Unlike the other countries, nominal volatility contributes to the histograms between Latvia and the United States in both periods as the dollar floats against both the lat and the euro. Relative prices are (if anything) more dispersed in 2014 between Latvia and the United States compared with 2012-2013, but the key finding is we do not see a meaningful change in the qualitative pricing pattern with the United States as we did with France, Germany, and Italy.

For simplicity and clarity, we do not show these patterns for other countries in and out of the euro zone, but the patterns do hold broadly (plots of other bilaterals are available from the authors). Plots of the euro zone countries like Netherlands or Ireland, for example, look essentially the same as those of France, Germany, and Italy. Plots of the relative prices of Latvia with countries outside of the euro zone like China or Japan - or even with other euro-pegged countries like Denmark - look essentially the same as the plots of the relative prices of Latvia with the United States. The only exceptions that we have identified are Portugal and Spain, which as discussed in Cavallo, Neiman, and Rigobon (2014), have prices which are equal to each other but which differ from the rest of the euro zone. As such, we find no convergence of prices in Latvia and these countries when Latvia entered the euro zone.

\subsection{The Timing of the Price Convergence}

Latvia entered the euro zone on January 1st, 2014. Above, we demonstrated that this generated significant convergence in the prices of Zara goods in Latvia with other euro zone countries. When did this convergence occur?

We find that adjustment of prices occurs almost instantaneously, and started, in fact, slightly before January 1st. Figure 2 plots separately the percent of continuing goods that experienced a price increase and a price reduction in each week in Latvia, France, Germany, and Italy. ${ }^{11}$ The lines are generally quite close to the x-axis, indicating that most prices do not change in a typical week. Indeed, less than 1 percent of prices change in the median week in all four countries. There are a few weeks, however, in which a large share of prices are reduced as part of seasonal sales. For example, the long-dashed lines spike upward in mid-2013 in all the plots, with between 20 and 50 percent of prices decreasing in each of several consecutive weeks. In this regard Latvia's pre-euro price change pattern resembled that in the euro zone countries.

\footnotetext{
${ }^{11}$ We exclude a small number of weekly observations where the number of collected prices drops below 1000 and omit week 26 of 2013 for Germany, week 27 of 2013 for Latvia and France, and week 28 of 2013 for Italy, where the spikes in price levels suggest possible problems with the scraping algorithm (though none of our conclusions are affected if in fact those observations are correct).
} 
In the run-up to 2014, the lines for France and Italy remained at precisely zero while fluctuations in the lines for Germany were highly muted. None of those countries experienced a meaningful share of price changes before the new year. Latvia, by contrast, experienced a slow but steady increase in the share of price changes (both increases and reductions) in December. 2 percent of Latvia's prices changed in each of the first two weeks of December, 5 percent of Latvia's prices changed the third week, and 3 percent of Latvia's prices changed in the last week of 2013.

In the first week of 2014, when Latvia officially joined the euro zone, 90 percent of its prices (in levels of local currency) changed. ${ }^{12}$ This spike should not be attributed entirely to the currency regime change. After all, the share of price changes in France, Germany, and Italy all also spiked upward that week - Zara clearly has a large sale in event in January. But Latvia's 90 percent level is significantly above the peaks in the other euro zone countries, which range from about 30 to 60 percent. Further, the short-dashed line is the primary mover during the first week in January, indicating most price changes were increases, which differs from what occurred in the other three countries. We conclude, therefore, that nominal price rigidity did not play a meaningful role in shaping Latvia's relative price adjustment upon entering the euro zone. ${ }^{13}$

Figure 3 demonstrates that these price changes were in fact such that Latvia's prices generally converged to equal those in the other euro zone countries. We plot for four bilateral pairs with Latvia the time series of the share of products with log real exchange rates of magnitudes less than 0.01 (i.e. $\left|q_{i j}(z)\right|<0.01$ ). Starting with the top left plot, we see that the share of goods sold at essentially the same price in Latvia and France is roughly 6 percent for most of 2013 . In December 2013, as Latvia approached its date of entry for the euro, this share starts rising and then in the first week of January, this percentage jumps to about 50 percent and continues to rise. By February, the share of products with identical prices reaches more than 85 percent, and it remains at this elevated level - in fact, closer to 90 percent - through the end of our data in mid-2014, consistent with the histograms in Figure $1 .^{14}$

Unsurprisingly, the patterns in Germany and Italy exactly mirror those in France. By contrast, Latvia's adoption of the euro in 2014 does not carry with it a sharp change in the share of goods priced identically in Latvia and the United States. That share continues to fluctuate near to 6

\footnotetext{
${ }^{12}$ The units on all prices changed during this week. The 10 percent of price levels that did not change refer to cases where the level in lats at the end of 2013 equaled the level in euros in early 2014, such as if a good's price was 27.99 lats in the last week of December 2013 and was 27.99 euros in the first week of January 2014.

${ }^{13}$ For technical reasons, our scraping algorithm excluded temporary sales in January 2013, but added them subsequently. As a result, there is no comparable spike in price reductions in January 2013 as in January 2014.

${ }^{14}$ We believe this pattern to be accurate, but do not emphasize the fact that adjustment took 1-2 months because we cannot rule out that scraping errors resulted in the exclusion of some goods in January, making it appear as though their price changes occurred in February.
} 
percent, the same as the pre-2014 levels between Latvia and the euro zone countries.

Finally, we plot in Figure 4 the time series of the median and mean absolute value of goodlevel log real-exchange rates, or the median and mean of $\left|q_{i j}(z)\right|$, for the same four bilateral pairs with Latvia. We weight all prices equally and drop a handful of weeks in which the number of products captured fluctuates spuriously due to scraping errors. Starting again with France, we see the median absolute value of relative prices at about 7 percent, a level largely stable through 2012 and 2013, rising to 8 percent by the end of 2013.

During the first week of 2014, the median gap immediately closes to approximately zero. There is no steady convergence nor overshoot. Further, the convergence is persistent through the end of our dataset and is not merely a function of the transition rules (discussed above) set to govern price adjustment during the first two weeks of 2014. In fact, note that a sizable share of the price adjustments made Zara's products more expensive, not cheaper, in Latvia. Price convergence for these goods was obtained almost instantaneously. (Our data do not allow us to robustly conclude whether this adjustment generally increased or decreased average prices throughout the country. The unweighted average or median relative price in these data, for example, is highly volatile.) The mean absolute value behaves similarly, starting and ending a few percentage points above the median line.

As with Figure 3, the time-series plots for Germany and Italy follow that for France, while that for the United States differs. ${ }^{15}$ Goods since 2012 have been priced in Latvia and the United States at levels that typically differ between 10 and 20 percent, with no obvious trend or break. The fluctuations of 5-10 percent with the United States in part reflect movements in the nominal exchange rate.

\subsection{Is this Surprising?}

In sum, we demonstrate that for thousands of goods sold by Zara in 2012-2013, large differences existed between prices in Latvia and other countries, including those in the euro zone. This is, on its own, quite surprising, since Latvia had a hard and credible exchange rate peg to the euro during 2012-2013. It is therefore even more shocking that immediately upon adopting the euro in 2014, most of these price differences collapsed, with the median deviation between Zara and France (or Germany or Italy) equaling zero. As an empirical matter, the results are quite clear: at least for some set of products, the adoption of a common currency per se, not the elimination of nominal volatility, results in rapid and dramatic price convergence.

\footnotetext{
${ }^{15}$ We do not put much emphasis on short-lived jumps up or down in the series, such as that in Germany in mid-2013, as scraping errors will ocassionally produce weeks with a very small number of items.
} 
From the standpoint of sticky price models, one might interpret these results as indicating that price setting is state-dependent at the time countries change their currencies, even if these results do not rule out time-dependent models both before and after the changeover. This is important, however, as it allows the possibility that the real exchange rate behaves differently when a country revalues its peg as compared to when a country joins or exits a currency union from a non-unitary peg. ${ }^{16}$ Nearly all open-economy models with sticky prices, from Obstfeld and Rogoff (1995) to Gali and Monacelli (2005) to Farhi and Werning (2012), either explicitly or implicitly ignore the distinction between a pegged exchange rate and a currency union and model these cases identically. This equivalence in standard theoretical models would certainly apply to Latvia as its nominal exchange rate was tightly fixed against the euro for nearly a decade preceding its entry to the euro zone.

What drives this pricing behavior? As we elaborate in Cavallo, Neiman, and Rigobon (2014), there does not appear to be a simple answer. ${ }^{17}$ Pegged regimes might generate different pricing behavior due to expectations of the possibility that the peg will not be maintained. With sticky prices or costly price adjustment, current prices are set with knowledge of the possibility that they will exist in a future state with a different nominal exchange rate. But this dynamic seems unlikely to explain different clothing prices in countries pegged to, rather than inside of, the euro zone. Zara's typical items change each season and are sold on the spot market to customers. Unlike goods that last a long time and for which long-term price guarantees are made - such as for business-to-business transactions on custom-made intermediate inputs, for example - Zara faces trivial risk of being "stuck" with suboptimal prices were Latvia to exit its peg.

A reasonable initial hypothesis would be simply that barriers to arbitrage were lifted with Latvia's entry to the euro. But we cannot identify any meaningful barrier that was lifted in tandem with the currency regime change. Flows of people and goods, and even of some regulations governing transportation and shipping, are dictated at the EU level, not the euro zone level. Latvia's entry to the euro zone did not impact in any relevant way its prexisting membership in the EU.

\footnotetext{
${ }^{16}$ See Cochrane (2012) for a discussion of this idea in the context of predictions of a Greek exit from the euro zone. In such a hypothetical, were prices to quickly adjust as in state-dependent models, any real exchange rate movement would be muted.

${ }^{17}$ We have spoken to a number of current and former employees (and reached out to more) of several companies that exhibit this pricing behavior, including Zara, but so far have been unable to ascertain why this pattern emerges. One difficulty is that pricing strategies constitute highly sensitive information for the companies. Some companies have told us they choose "pricing regions" based on market similarities, and the euro clearly constitutes one such a pricing region. It remains unclear, however, why the degree of "market" similarity would change so dramatically the day a country enters a currency union, nor why euro zone countries as different as Germany and Greece would be considered by some companies to be more similar than Germany and Denmark, which is outside of the euro zone but whose kroner is pegged to the euro.
} 
It is plausible that companies like Zara organize pricing departments by currency, with a different person or unit in charge of euro prices, dollar prices, lat prices, etc. This would imply that on December 31st, 2013, Latvian prices and German prices were set by different people whereas this changed on January 1st. While this may be, in a mechanical sense, the cause of this pricing pattern, it is extremely difficult to write a model in which structuring pricing units in this way would prove optimal. ${ }^{18}$

More likely, we speculate, is that companies like Zara feel pressure not to anger customers whose expectations are that prices are equalized within the common currency zone. This was, after all, one of the principal arguments made by governments of would-be member countries in favor of adoption of the euro. ${ }^{19}$ In this sense, at least, the euro does in fact seem to have in part delivered on its promise.

\subsection{Does this Hold for Other Companies?}

In this paper we demonstrate rapid and significant convergence in prices when Latvia entered the euro zone. Cavallo, Neiman, and Rigobon (2014) uncovered the related pattern that prices were equalized in the cross-section of more than a dozen euro zone countries. In addition to prices for Zara, the focus of this paper, our earlier work studied the prices for Apple, H\&M, and IKEA. Of these three companies, only H\&M operates a web page in Latvia. Before Latvia's adoption of the euro, H\&M's prices typically differed between Latvia and the euro zone countries by magnitudes of about 10 percent, much as was the case for Zara's prices.

Starting in early 2014, H\&M's webpage stopped showing prices for Latvia due to what their customer service described as "technical reasons". At the time of writing, prices had not yet been restored, though customer service informed us prices in Latvia will equal those in Estonia, which is a member of the euro zone and generally has the same prices as France, Germany, and Italy for goods from H\&M and Zara. Therefore, we very much suspect that Latvia experienced convergence with the euro zone in its prices on H\&M goods as well, though we cannot know for certain until H\&M again posts its online prices.

Though Cavallo, Neiman, and Rigobon (2014) focused on four primary retailers for which we had the most data, we also demonstrated lower price dispersion within the euro zone for more

\footnotetext{
${ }^{18}$ In this sense, our results call for further work on pricing at the intersection of industrial organization and macro, along the lines of Carlton (1989), Zbaracki, Ritson, Levy, Dutta, and Bergen (2004), Neiman (2010, 2011), Hellerstein and Villas-Boas (2010), and Hong and Li (2013).

${ }^{19}$ If price comparisons are the key driver of our results, however, it would be surprising that companies make it so easy for consumers to identify a given identical product in multiple countries. See, for example, Carlton and Chevalier (2001), which evaluates the extent to which simple tactics are used in other industries to deal with channel conflict arising from online discount retailers.
} 
limited data on products sold by Adidas, Dell, Mango, and Nike. Of those four companies, only Mango posts online prices in Latvia. Our data for Mango is more limited than what we have for Zara, but Latvia's entry into the euro does not appear to have brought a significant reduction in dispersion of Mango's prices between Latvia and the euro zone countries. ${ }^{20}$ Mango's Latvian pricing strategy, however, appears to be an exception for international clothing retailers operating in Latvia. We collected an additional sample of 200 online prices, 10 each from 10 additional clothing retailers with physical stores in Latvia and Germany: Armani, Bershka, Burberry, Dolce \& Gabanna, Lululemon, Massimo Dutti, MaxMara, Next, Pull and Bear, and Tommy Hilfiger. We find that nine of the retailers post identical euro prices in Latvia and Germany for all of the observed goods, with Dolce \& Gabanna as the exception. ${ }^{21}$

\section{Conclusion}

We analyze a novel dataset of prices from Zara, the world's largest clothing retailer, collected with high frequency before and after Latvia entered the euro zone. Though Latvia's currency regime change was from a hard peg with the euro to the euro itself, and therefore did not involve a reduction in nominal volatility, price differences with euro zone countries like France, Germany, and Italy collapsed significantly and immediately. Whereas 6 percent of the goods sold in Latvia and Germany in November 2013 had the same price, about 85 percent did by the end of January 2014 and about 90 percent did by the end of February 2014. Our results suggest that standard models may omit key pricing considerations the play a role in currency unions but not in pegged regimes, and offer proof that at least one of the original goals of the euro zone has in fact materialized.

Latvia's adoption of the euro proves a useful natural experiment in many ways. Latvia was already a member of the EU, so the monetary regime change was not accompanied by changes in other relevant policies such as tariffs. Latvia changed from a fixed exchange rate regime, so nominal volatility played no role in our results. And Latvia is quite small relative to the euro zone, limiting the plausible scale of general equilibrium effects. Infererence from this episode is appropriately applied, we therefore believe, to other similar episodes for similar goods.

Would similar pricing dynamics ensue if a much larger country entered a currency union? Or if a country exited the euro zone unexpectedly? We hope further research sheds light on these

\footnotetext{
${ }^{20}$ We note that of the 8 companies studied in Cavallo, Neiman, and Rigobon (2014), the difference in price dispersion between currency unions and pegs was weakest for Mango.

${ }^{21}$ We collected these data after Latvia's entry to the euro, so cannot comment on how these stores priced under the previous pegged regime.
} 
critical but open questions. 


\section{References}

Bacchetta, P., and E. V. Wincoop (2005): "A Theory of the Currency Denomination of International Trade," Journal of International Economics, 67(2), 295-319.

Bems, R., and J. Di Giovanni (2014): "Income-Induced Expenditure Switching," Working Paper.

Blanchard, O., and F. Giavazzi (2002): "Current Account Deficits in the Euro Area: The End of the Feldstein-Horioka Puzzle?," Brookings Papers on Economic Activity, 2, 147-209.

Boivin, C., R. Clarck, And N. Vincent (2012): "Virtual Borders," Journal of International Economics, 86(2).

Carlton, D. (1989): "The Theory and the Facts of How Markets Clear: Is Industrial Orgnization Valuable for Understanding Macroeconomics?," in Handbook of Industrial Organization, ed. by R. Schmalense, and R. Willig, pp. 910-943. North-Holland, New York.

Carlton, D., And J. Chevalier (2001): "Free Riding and Sales Strategies for the Internet," The Journal of Industrial Economics, 49(4), 441-461.

Cavallo, A. (2012): "Scraped Data and Sticky Prices," Working Paper.

Cavallo, A., B. Neiman, and R. Rigobon (2014): "Currency Unions, Product Introductions, and the Real Exchange Rate," The Quarterly Journal of Economics.

Cochrane, J. (2012): "Should Greece Devalue," Blog Post (url = http://johnhcochrane.blogspot.com/2012/01/should-greece-devalue.html).

Devereux, M., C. Engel, and P. Storgaard (2004): "Endogenous Pass-through when Nominal Prices are set in Advance," Journal of International Economics, 63(2), 263-291.

Dvir, E., And G. Strasser (2014): "Does Marketing Widen Borders? Cross-Country Price Dispersion in the European Car Market," Working Paper.

Engel, C., AND J. Rogers (2004): "European product market integration after the euro," Economic Policy, 19(39), 349-384.

FARHI, E., AND I. Werning (2012): "Fiscal Multipliers: Liquidity Traps and Currency Unions," Working Paper.

FRIBERG, R. (1998): "In which currency should exporters set their prices?," Journal of International Economics, 45, 59-76.

Friberg, R., and T. Matha (2004): "Does a common currency lead to (more) price equalization? The role of psychological pricing points," Economics Letters, 84(2), 281-287. 
Gali, J., And T. Monacelli (2005): "Monetary Policy and Exchange Rate Volatility in a Small Open Economy," The Review of Economic Studies, 72, 707-734.

Gil-Pareja, S., And S. Sosvilla-Rivero (2008): "Price Convergence in the European car market," Applied Economics, 40(2), 241-250.

(2012): "Convergence in car prices among European countries," Applied Economics, $44(25), 3247-3254$.

Goldberg, L., And C. Tille (2008): "Vehicle Currency Use in International Trade," Journal of International Economics, 76(2), 177-192.

GoldberG, P., And F. Verboven (2005): "Market Integration and Convergence to the Law of One Price: Evidence from the European Car Market," Journal of International Economics, $65,49-73$.

Gopinath, G., O. Itskhoki, and R. Rigobon (2010): "Currency Choice and Exchange Rate Pass-through," American Economic Review, 100, 304-336.

Gorodnichenko, Y., and O. Talavera (2014): "Price Setting in Online Markets: Basic Facts, International Comparisons, and Cross-Border Integration," Working Paper.

Handbury, J., And D. Weinstein (2013): "Goods Prices and Availability in Cities," Working Paper.

Hellerstein, R., and S. B. Villas-Boas (2010): "Outsourcing and Pass-through," Journal of International Economics, 81(2), 170-183.

Hong, G. H., And N. Li (2013): "Market Structure and Cost Pass-Through in Retail,” Working Paper.

Kaplan, G., and G. Menzio (2013): "Shopping Externalities and Self-Fulfilling Unemployment Fluctuations," Working Paper.

Nakamura, A., E. Nakamura, and L. Nakamura (2011): "Price dynamics, retail chains and inflation measurement," Journal of Econometrics, 161(1), 47-55.

Neiman, B. (2010): "Stickiness, Synchronization, and Passthrough in Intrafirm Trade Prices," Journal of Monetary Economics, 57(3), 295-308.

- (2011): "A State-Dependent Model of Intermediate Goods Pricing," Journal of International Economics, 85(1), 1-13.

Obstfeld, M., And K. Rogoff (1995): "Exchange Rate Dynamics Redux," Journal of Political Economy, 103(3), 624-660. 
Parsley, D., And S.-J. Wei (2008): "In Search of a Euro Effect: Big Lessons from a Big Mac Meal?," Journal of International Money and Finance, 27(2), 260-276.

Rose, A. (2000): "One money, one market," Economic Policy, 30, 7-33.

SimonovskA, I. (2011): "Income Differences and Prices of Tradables: Insights from an Online Retailer," Working Paper.

Zbaracki, M., M. Ritson, D. Levy, S. Dutta, and M. Bergen (2004): "Managerial and customer costs of price adjustment: direct evidence from industrial markets," Review of Economics and Statistics, 86(2), 514-533. 


\begin{tabular}{|c|c|c|c|c|c|c|}
\hline & World & Latvia & France & Italy & Germany & United States \\
\hline \multicolumn{7}{|l|}{ Panel A: 2012-2013 } \\
\hline Currency Regime & & pegged & euro zone & euro zone & euro zone & float \\
\hline $\begin{array}{l}\text { Ave. Exchange Rate } \\
\text { (\# euros per LCU) }\end{array}$ & & 1.4 & 1 & 1 & 1 & 0.75 \\
\hline $\begin{array}{l}\text { \# of Products } \\
\text { (Ave. per Month) }\end{array}$ & 5,070 & 3,652 & 3,491 & 3,768 & 3,676 & 3,549 \\
\hline $\begin{array}{l}\text { Prices (in euros) } \\
\text { 25th Percentile } \\
\text { 50th Percentile } \\
\text { 75th Percentile }\end{array}$ & $\begin{array}{l}25.95 \\
39.95 \\
60.81\end{array}$ & $\begin{array}{l}26.98 \\
36.98 \\
51.41\end{array}$ & $\begin{array}{l}25.95 \\
39.95 \\
49.95\end{array}$ & $\begin{array}{l}23.95 \\
39.95 \\
49.95\end{array}$ & $\begin{array}{l}23.95 \\
39.95 \\
49.95\end{array}$ & $\begin{array}{l}26.93 \\
44.47 \\
61.34\end{array}$ \\
\hline \multicolumn{7}{|l|}{ Panel B: 2014} \\
\hline Currency Regime & & euro zone & euro zone & euro zone & euro zone & float \\
\hline $\begin{array}{l}\text { Ave. Exchange Rate } \\
\text { (\# euros per LCU) }\end{array}$ & & 1 & 1 & 1 & 1 & 0.73 \\
\hline $\begin{array}{l}\text { \# of Products } \\
\text { (Ave. per Month) }\end{array}$ & 6,515 & 3,962 & 4,476 & 4,153 & 4,033 & 4,635 \\
\hline \multicolumn{7}{|l|}{ Prices (in euros) } \\
\hline 25th Percentile & 21.68 & 25.95 & 25.95 & 25.95 & 25.95 & 25.96 \\
\hline 50th Percentile & 36.33 & 39.95 & 39.95 & 39.95 & 39.95 & 43.22 \\
\hline 75th Percentile & 51.30 & 49.95 & 49.95 & 49.95 & 49.95 & 57.77 \\
\hline
\end{tabular}

Table 1: Number of Products and Price Statistics, Before and After Latvia Joined the Euro 


\section{France}
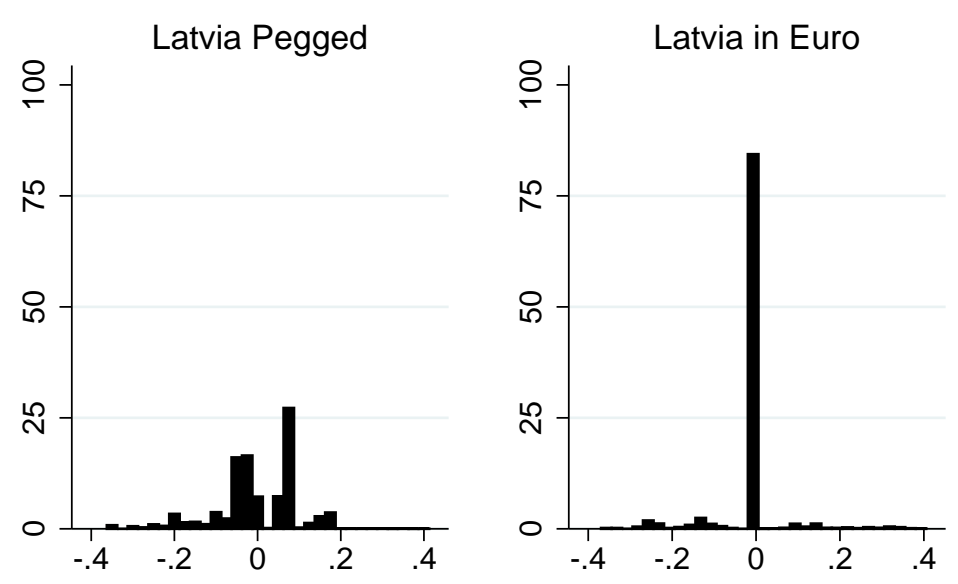

Italy
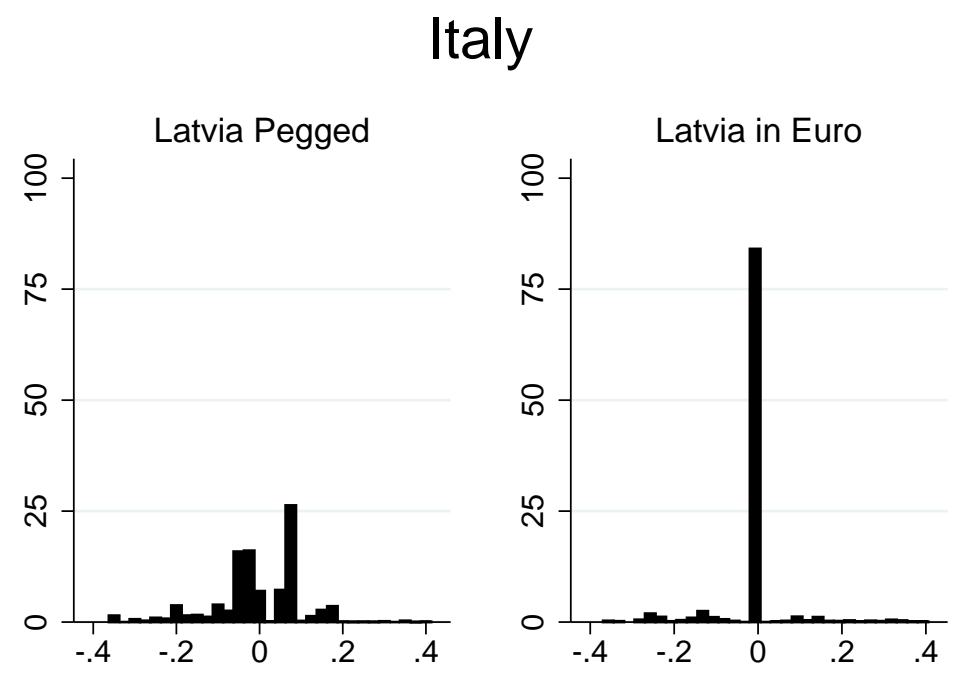

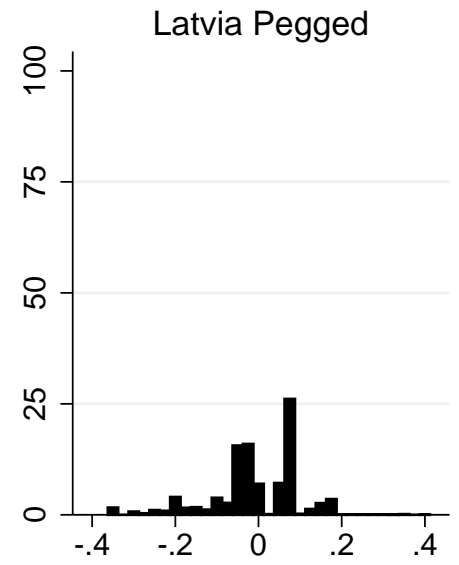

Germany
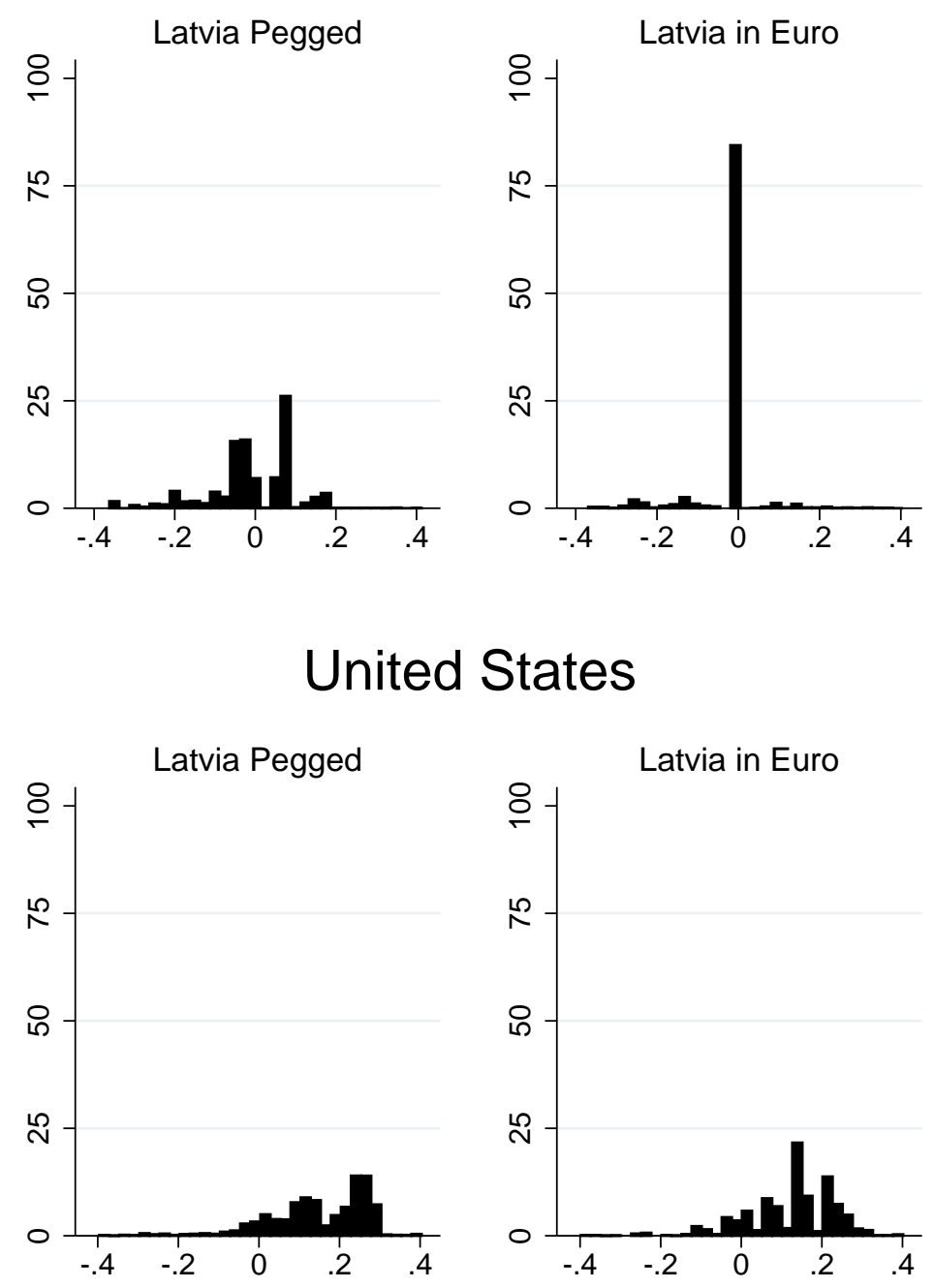

Figure 1: Histograms of Good-Level RERs $q_{i j}$ for Selected Bilateral Pairs with Latvia

Notes: Figures show $q_{i j}$ on the x-axes and the percent of observations on the y-axes, distinguishing data from before and after Latvia's adoption of the euro. All histograms include the bilateral relationship between the listed country and Latvia. We pool all good-week observations and exclude the small number of observations where $\left|q_{i j}\right|>0.40$. 

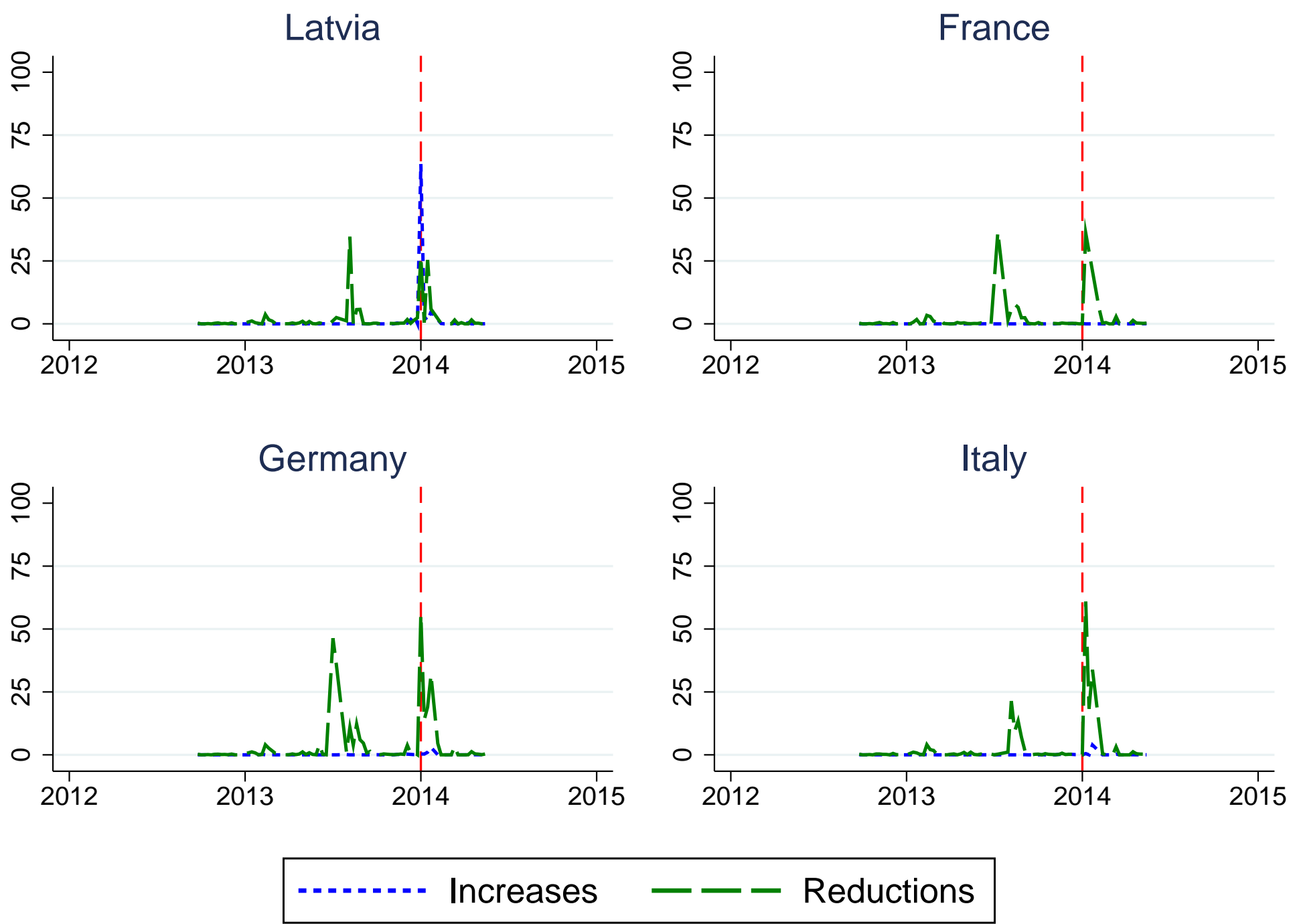

Figure 2: Share of Continuing Goods Experiencing a Price Change

Notes: Plots show the percentage of continuing (i.e. not new) goods that experience a price increase or decrease (in local currency) relative to the previous week. In Latvia's case, if a price equaled 100 lats in the last week of December and 100 euros in the first week of January, this would not be considered a price change. We exclude a small number of weekly observations where the number of collected prices drops below 1000 and omit week 26 of 2013 for Germany, week 27 of 2013 for Latvia and France, and week 28 of 2013 for Italy, where the spikes in price levels suggest possible problems with the scraping algorithm. 

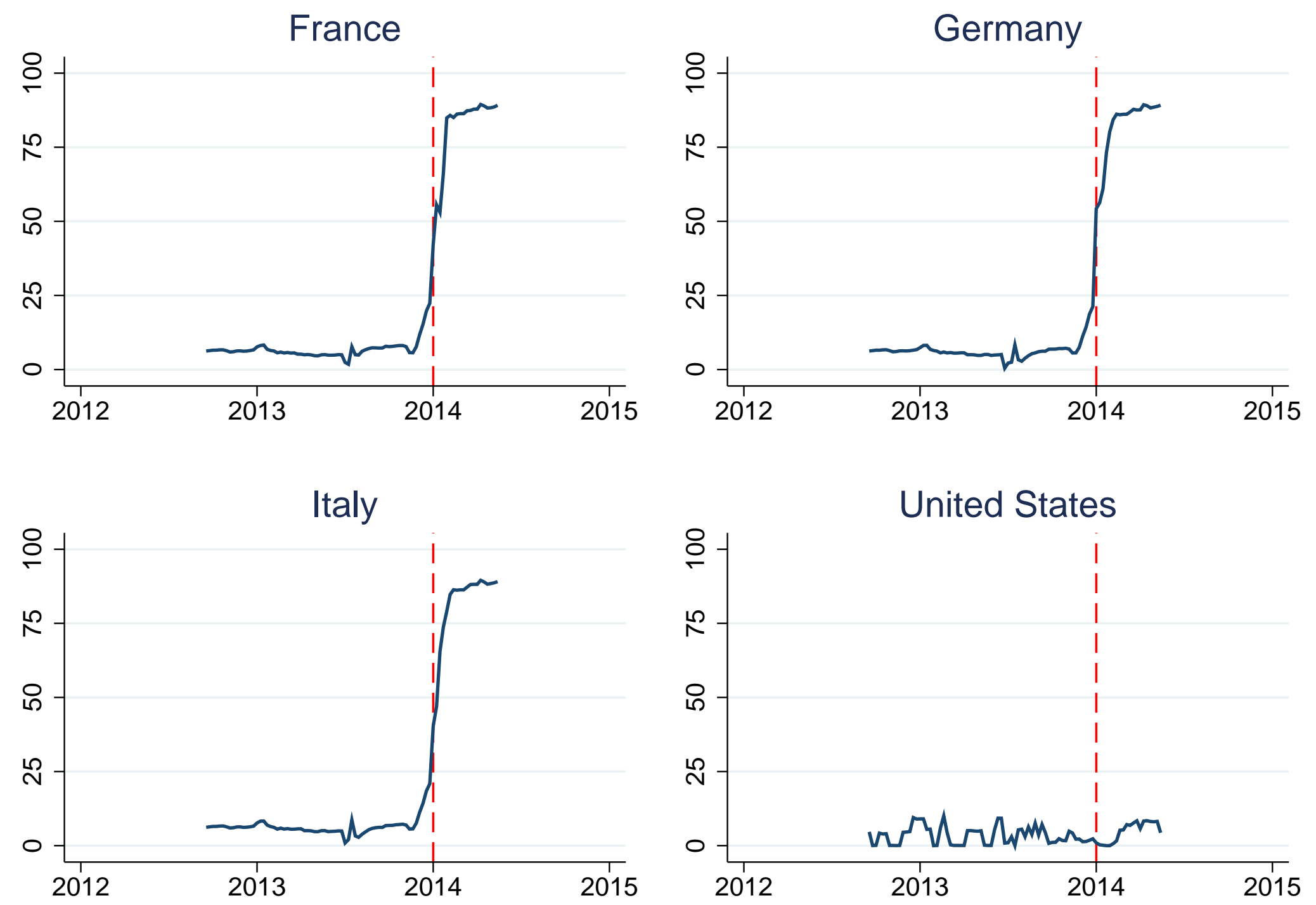

Figure 3: Share of Goods With Same Relative Price (Defined as $\left|q_{i j}\right|<0.01$ ) for Selected Bilateral Pairs with Latvia

Notes: Plots show the percentage of observed good-level relative prices between Latvia and the listed country of absolute value less than 1 percent $\left(\left|q_{i j}\right|<0.01\right)$, measured each week. We exclude the small number of observations where $\left|q_{i j}\right|>0.40$. 

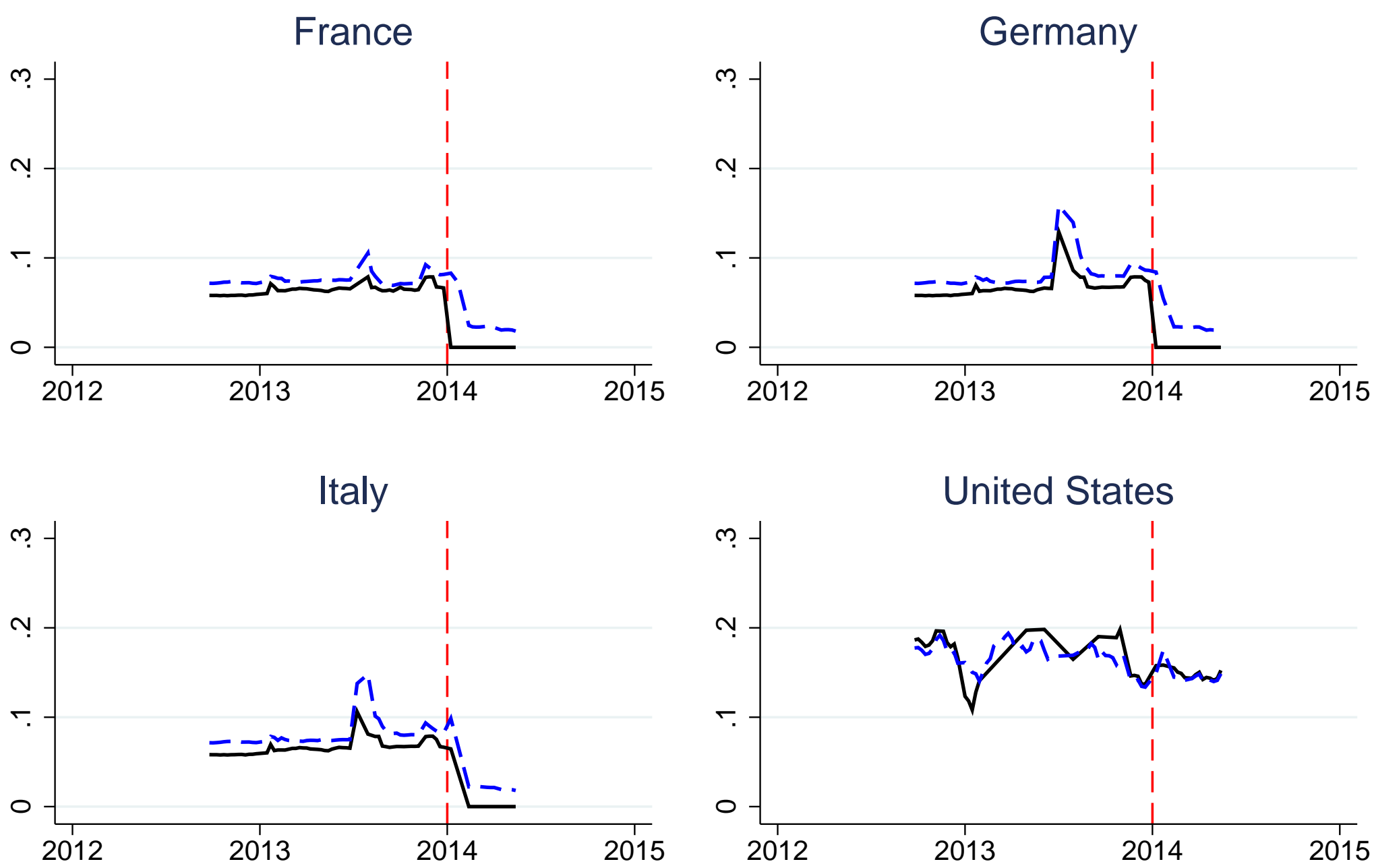

\section{Median - - - - Mean}

Figure 4: Median and Mean Absolute Values of Good-Level RERs $\left|q_{i j}\right|$ for Selected Bilateral Pairs with Latvia

Notes: Plots show the median and mean absolute value of good-level relative prices between Latvia and the listed country, measured each week. We exclude the small number of observations where $\left|q_{i j}\right|>0.40$. We also exclude the 26 th week of 2013 for Germany and the 27th week of 2013 for Italy, where we presume scraping errors caused implausible jumps in the series. 